\title{
CLR and Preservation
}

The deterioration of library materials has become an increasingly critical problem. Many of the programs devoted to finding solutions during the last twenty-five years have been sponsored by the Council on Library Resources $(C L R)$, a private, operating foundation. CLR grants supported chemical and applied research in the causes of paper deterioration, helped to establish conservation laboratories, and supported development of new equipment and tests. CLR also has assisted in attempts to establish cooperative preservation programs and to spell out a national strategy. Recent events show a heightened awareness of the problem; several new programs and promise of increased funding give hope for the future.

$\mathbf{I}$ IN A FULL-PAGE COLOR PHOTOGRAPH in the April 1980 issue of Smithsonian magazine, Library of Congress restoration officer Peter Waters stands enveloped in a shower of paper fragments, the remains of a scholarly work blown from his open hand by a puff of exhaled air. No more dramatic testimony is needed to illustrate the danger the United States is in "of losing its mind." 1 The history of why millions of books, journals, manuscripts, and other paperbound records of our cultural and intellectual inheritance are deteriorating has been carefully documented. Indeed, in the last twenty-five years, a litany of shocking examples of decay and calls to action has rung repetitiously through the literature, often with quite positive results. Activity on many fronts has led to substantial chemical research and laboratory testing, to the establishment of preservation programs in individual institutions, and to cooperative efforts to ensure preservation of specific categories of materials. Yet, despite this attention, the disparity that Edwin Williams pointed out in 1969 "between the alarming statements that have been published and the alarm that has been generated in individuals, even historians,

Nancy E. Gwinn, formerly program officer at the Council on Library Resources, is associate director for program coordination for the Research Libraries Group, Inc., Stanford, California . remains."2 It persists because the deterioration is passive, largely unnoticed by the library user until a book or journal is requested and the pages begin to crumble in the hand.

Much of what has been accomplished in the last quarter of a century has been made possible through an array of grants furnished and programs administered by the Council on Library Resources, Inc. (CLR), an independent, private, operating foundation established in 1956 by the Ford Foundation. In recognition of the seriousness of the problem of deterioration of library materials, within its first year of operation CLR initiated a study of the causes. Since that time, the council has authorized expenditures of more than $\$ 2.5$ million on preservation-related activities.

Periodically, however, it is necessary for the foundation to reassess its role, review its past efforts, and use the insights gained to devise new strategies for the future. This is in part a desire to analyze and learn from past failures and build on successes. But it is also a response to change, both external and internal. A recent change in the council's presidency provided the occasion for a total review of its programs and priorities. A change from the single benefaction of one foundation to multifoundation support of the council's program reinforced the need for such a review. But of more importance, 
perhaps, is the increased attention of others, some such as the National Endowment for the Humanities (NEH) and the Department of Education with far greater resources, to the possibility of loss of part of our heritage and the impact of that loss on the future of scholarship.

The purpose of this paper is to review and summarize the council's preservation program, to discuss its present activities, and to set forth some ideas on the future of council activity in this critical area. The council has in the past also worked hard to assist in improving microform technology, which has considerable benefit both for preserving the intellectual content of books, journals, and other documents and for making them more accessible. Projects involving the design of prototype equipment or systems have not been included here, nor have CLR-supported microfilming projects, unless their principal objective was for preservation.

Although the limits to its resources have, from its genesis, prevented the council from assisting individual institutions in preserving their collections, the council has consistently searched for programs that would advance the knowledge and techniques of all libraries by attacking the root causes of the problem and assisting the development of mechanisms to overcome them. CLR programs thus can be readily grouped into two categories: (1) research, analysis, and dissemination; and (2) national planning.

\section{RESEARCH, ANALYSIS, AND DisSEmination}

Lack of information about the causes of deterioration, coupled with a lack of understanding about what was in fact known, was clearly the most critical problem in the field of preservation in the 1950s. The obvious need was for research, both pure, chemical research to determine the reasons for the increasingly swift decay of paper, and applied research to develop techniques to combat it. Finally, dissemination of results, procedures, and techniques to those in a position to act was imperative.

\section{William J. Barrow Research Laboratory}

Central to any discussion of council activity in preservation research is the figure of William J. Barrow and the research labora- tory that bore his name. A document restorer at the Virginia State Library, Barrow invented a lamination process to protect valu able manuscripts and records. But he worried that papers would continue to deteriorate inside the lamination, and this stimulated him to begin a series of investigations concerning causes and remedies. His study ended only with his death in 1967, although the work he started subsequently continued for some time.

Prior to becoming the first president of the council, Verner W. Clapp worked for many years at the Library of Congress (LC). An amateur bookbinder, Clapp acquired various responsibilities at the library, which included the repair of documents, binding, and preservation. $\mathrm{He}$ and Barrow became acquainted, and a warm personal and creative professional relationship developed that was to have a fruitful result, as revealed in a 1968 letter from Clapp to Barrow's son:

While I was still at LC your father and I used to discuss the need for research in the bookmaterials area. However, while I was able to throw small commissions his way, LC had no research money. But in $1956 \mathrm{I}$ became president of the Council on Library Resources, Inc., and the road to research suddenly opened up. The rest is history. ${ }^{3}$

Convinced that acid was the chief cause of paper decay, in the 1940s Barrow developed a deacidification process based on the submerging of paper in baths of calcium hydroxide, calcium bicarbonate, and/or magnesium bicarbonate. He continued valuable studies of inks and old papers and published his findings with the help of Clapp, who had become his collaborator and unofficial editor. By 1957 Barrow was eager to begin an organized program of testing. In that year he was given the opportunity, under the auspices of the Virginia State Library and with funding from CLR in one of its first grants. By determining resistance to tearing and folding, Barrow tested paper from 500 books, published from 1900 to 1949 , that had "spent sheltered and temperate lives in the scholarly atmosphere of Virginia institutions." 4 Similar results were produced by testing freshly manufactured papers to which artificial aging techniques were applied. And the results were stagger- 
ing. "It seems probable," he said, "that most library books printed in the first half of the 20th century will be in an unusable condition in the next century." 5

As part of the same project, Barrow collected papers from the seventeenth and eighteenth centuries and subjected them to chemical analysis. As he reported in Science, the "acidity of the weakest papers is, on the average, from six to ten times as great as that of the strongest." 6 This was not a new discovery, nor was Barrow's identification of alum-rosin sizing and residual chlorides from bleaching as the perpetrators. But in this first investigation and more extensive later ones, also funded by CLR, the facts were documented as they never had been before. ${ }^{7}$

Barrow's findings disputed the prevailing theory of the time that paper deterioration was caused primarily by polluted urban, or industrial, atmosphere and that paper made entirely from rag would ipso facto be the strongest. Although pollution does play a role (and in some areas, such as New York City, a critical one), Barrow identified manufacturing processes as the principal cause of paper decay; in a later investigation of book papers manufactured from 1800 to 1899, he was able to trace historically the loss of strength in papers in a time line that matched the introduction by paper mills of alum sizing and the use of cheaper and shorter fibers. ${ }^{8}$

Barrow was convinced that a permanent and durable paper could be made that would avoid the pitfalls of the manufacturing process and still be economical. Accordingly, he developed specifications using chemical wood pulp and an alkaline sizing (Aquapel) that had recently come onto the market. An experimental run at the Herty Foundation and later tests at a commercial mill proved successful. ${ }^{9}$ Testing showed that the paper had an expectation of longevity comparable to that of the fine book papers of the past, yet it was within a medium price range. Named Permalife, the paper was manufactured for fifteen years by the Standard Paper Company. When Standard closed in the mid-1970s, Howard Paper Mills, Inc., of Dayton, Ohio, purchased the rights to Permalife, as well as Standard's inventory.
On September 16, 1960, the American Library Association and the Virginia State Library called a conference on permanent/ durable paper, to which were invited scientists who served Barrow as consultants, representative librarians, archivists, book publishers, book designers, printers, papermakers and merchants, paper chemists, and others. The purpose was "to explore the potential benefits for the users of books offered by the new chemical wood pulp paper. . . ."10 While there was enthusiasm among the participants familiar with the paper for its potential, the critics raised issues that have a familiar ring: "it would be wasteful and costly to try to upgrade the paper used for all books; much that was published was intended to be of only temporary use or was not in any case worth preserving; anything worth preserving would be reprinted if there was a need for it or if it became a 'classic'; it was impractical to publish part of an edition on permanent/durable paper unless a large group of libraries subscribed for all copies in such an edition; there would be problems of printability; and manufacturers would be hesitant to increase paper prices simply to increase permanence or durability on a large scale." "It was also noted that while consumers demanded much of publishers and papermakers, permanence and durability were seldom high on the list.

The conference group voted unanimously, however, to "invite the American Library Association to establish a continuing group, constituted to represent the various interested groups here, which would find necessary support to continue some discussion of this problem, looking toward mutually agreeable solutions." 12 Thus the ALA Joint Committee on Permanent/Durable Paper was born and was charged with reviewing Barrow's tentative specifications and, based on this review, with developing "acceptable standard specifications for paper of this or similar type, to establish standards on a national scale, to establish a suitable designation, to determine costs, to promote use, to develop a quality control program including testing, and to stimulate further research." 13 It proved to be too great a task. After one meeting, a stalemate occurred because of disagreements on, among other 
things, testing procedures. While an attempt was made to assess the printability and ease of handling of permanent/durable papers along with other promotional efforts, in 1968 ALA requested the council's permission to dissolve the committee because, as constituted and administered, it "was unwieldy and thus relatively ineffectual in accomplishing the assignment." 14 The council concurred, noting that the committee was "unable to realize the hopes that led to its establishment." 15

Up to the time of the 1960 conference, Barrow's investigations had been carried out with the meager resources of his restoration shop in the Virginia State Library. In 1961, at Clapp's suggestion and with the aid of council funds, he took advantage of the hospitality of the Virginia Historical Society to construct in its building a paper-testing laboratory employing the most exacting controls of temperature and humidity and devoted exclusively to problems of preservation of library materials. On August 1 he signed the first of a series of contracts with the council that continued for the next sixteen years.

Assembling a small staff, Barrow opened his laboratory with an investigation of an aerosol deacidification method that could be used on whole books, rather than separate pages, and with the development of methods for predicting the longevity of polyvinyl adhesives suitable for perfect bindings. He continued to study what had happened to book papers from the fifteenth through the nineteenth centuries, and he began to look at the effects storage temperatures have on the permanence of paper. $\mathrm{He}$ developed spot-testing procedures so that librarians and archivists would have a quick and easy method of distinguishing stable from unstable book and record papers. Not all of his work, however, was done under direct council sponsorship.

In 1959 the American Library Association began its Library Technology Project with the aid of a council grant. The project staff engaged the Barrow Research Laboratory on several efforts. One investigation led to an improved paper stock for use in the manufacture of library catalog cards. But the most important was the laboratory's assistance in ALA's development of stan- dards for library binding. Barrow and his staff participated in the research and development phase of this project, during which they established criteria for the performance of bindings used in libraries and designed testing equipment so that the performance could be measured.

The results of Barrow's work on many of these matters appeared in a series of booklets entitled Permanence/Durability of the Book. His reputation was growing in national and international spheres. In 1967, the American Library Association asked him to travel to England to consult with British paper manufacturers to ensure that a permanent/durable paper could be used for the pre-1956 imprint edition of the National Union Catalog, a work subsequently published by Mansell in more than 700 volumes. The final volumes are scheduled to be issued in 1981. Barrow found three British mills skilled in the use of alkaline size and eager to learn his techniques for properly preparing the necessary long fibers. He subsequently tested the paper produced and of that which was finally selected (manufactured by Guard Bridge Paper Company, Ltd.) said: "This has the highest strength characteristics and one of the best rates of deterioration of any 20th century book paper that we have tested in this laboratory." 16

Throughout the 1960s Barrow worked tirelessly to awaken the general public to the gravity of paper deterioration and the potential loss to society of its recorded heritage. He wrote extensively, stimulated others to publicize the enormity of the problem, and was himself the subject of several articles. Perhaps because of his nonscientific background, he was able to tell his story in terms easily understood. An editorial, "The Paper Man," in the Richmond News Leader of June 8, 1963, is ample illustration:

So off we went to Battle Abbey (the building housing the Virginia Historical Society), past rows of great Virginians peering with portrait eyes, down stairs to talk to Mr. Barrow over a bowl of apples and pears. "See," he said, taking a yellowed book off a shelf of yellowed books. It was an old cookbook, "Printed in 1905," he said, as page 282 came out in his fingers. We folded the paper over; then back. Two folds were all the 
paper could take. The page fell into two pieces, and the recipe for Chicken a la Terrapin was cut in half.

There were, of course, critics of Barrow's results. Some thought Barrow's specifications for permanent/durable paper might be "excessively high" or "not really practical" for all except a few percent of the users of printed materials. Indeed, a later project of the laboratory, under contract with CLR and the Library of Congress, was a revision of the specifications, but they were not substantially lowered, and eight of thirty-two commercial papers were found to meet them. The close relationship between Barrow and the Standard Paper Company was viewed with disfavor by some manufacturers, who thought that Barrow did not give enough recognition to others who were producing alkaline papers. It was reported that the rag paper manufacturers had their own group that as a whole had been questioning Barrow's accomplishments in the permanent/durable paper field. But his reputation and the quality of his work survived these mild criticisms, and his efforts continue to inspire those who are working today on finding solutions to one of the library world's most baffling problems.

Following Barrow's death, his wife and son determined to carry on the laboratory, and the council agreed to support a continuance of the projects Barrow had begun. Dr. R. N. Dupuis, retired from a position as vice-president in charge of research at the General Foods Corporation and one of Barrow's consultants, was hired to direct the laboratory on a part-time basis. In 1971, it was determined that the laboratory would benefit from full-time direction, and Dr. Bernard F. Walker, formerly corporate director of research for the Huyck Corporation, a manufacturer of components for the paper industry, was appointed. Dr. Dupuis continued his association with the laboratory, however, as an official CLR representative, serving on site in Richmond as liaison in scientific and policy matters.

In the post-Barrow period, work continued at the laboratory on the effects of temperature and humidity on the permanence and durability of paper. Laboratory staff also continued studying the characteristics of centuries-old book papers and tested some modern papers for the Library of Congress and others, although care was taken throughout the history of the laboratory to keep its focus on research rather than quality control. But its first major activity under Dupuis' direction was to evaluate a British vapor-phase paper-deacidification method. This activity laid the groundwork for the laboratory's principal focus for the next ten years.

In 1966, W. H. Langwell, a British liquor chemist, developed a vapor-phase deacidification process for books and documents. The process used cyclohexylamine carbonate (CHC), which was applied by interleaving books with treated absorbent paper or by placing granules of pellets, loose or in sachet form, in manuscript boxes. Informed of the matter by a British colleague, Louis B. Wright, the council's vice-chairman, alerted Verner Clapp who, with Barrow's agreement, thought the method should be tested.

In its conclusions, the laboratory stated that $\mathrm{CHC}$ increased the $\mathrm{pH}$ of book papers as well as their resistance to folding and tearing. It appeared to affect the rosin sizing, however, and also decreased the brightness and fluorescence of the papers treated.

More important, however, the laboratory confirmed that $\mathrm{CHC}$ hydrolyzes to cyclohexylamine, an odorous and toxic chemical, on exposure to moist air often found in libraries. An opinion from the Food and Drug Administration confirmed that "Cyclohexylamine has both carcinogenic and mutagenic potential. ..."17 As a result of the laboratory's report, the Process Materials Corporation, a U.S. distributor of the CHC products, which had already suspended sales, removed the products completely from the market. ${ }^{18}$

Nevertheless, the thought that someone had found a vapor capable of deacidifying entire books excited laboratory staff, who began searching for a nontoxic substance that might achieve the same end. At a July 1969 meeting of the laboratory's advisory group, to which were added representatives of the American Library Association (ALA), the Association of Research Libraries (ARL), the Center for Research Libraries, and others, the possibility of discovery of new 
methods of vapor-phase deacidification received serious attention as one of the three highest priorities for the laboratory. "What is needed," the group concluded, "is a onetime mass process not requiring unbinding of the treated books."19

The laboratory experimented with several substances, even securing a patent on one (a vapor caused by the reaction of ammonia and formaldehyde to form a solid, hexamethylenetetramine), but none seemed entirely satisfactory. Then, in July 1970, one of the laboratory's consultants suggested that morpholine, a common chemical used at that time in many floor waxes and polishes, be used to stabilize cellulose with respect to $\mathrm{pH}$. By December, the laboratory was able to report surprising results in terms of the capacity of morpholine to deacidify paper. The laboratory tested several other amines, but morpholine continued to be the most satisfactory. Sophisticated hardware for administering the vaporphase treatment was also designed and tested. After years of painstaking experimentation patents were obtained on two versions of the process, one using a strong concentration of morpholine, the other a mild. While the strong process produced excellent results when applied to unbound books, the mild version was considered more suitable for mass deacidification users, since it could be used without harm to books bound with pyroxylin-impregnated cloth, a common feature of library bindings.

In 1975, the laboratory phase of the development of the morpholine deacidification process was brought to a close. With matching funds from the National Endowment for the Humanities and the council, the Virginia State Library and the Barrow Laboratory began a large-scale test of the process using custom-made equipment, manufactured by the Vacudyne Altair Corporation of Chicago, capable of processing fifty books at a time. At a meeting, sponsored by the American Chemical Society in 1976, the laboratory's director, Dr. Walker, summarized the advantages and disadvantages of the process.

The morpholine process, he stated, deacidified about eighty to ninety pounds of books in sixty minutes, at an estimated total cost (at that time) of about thirty-two cents a pound. The process could be used without likelihood of damage to 99 percent of the normal books found in libraries, and their life expectancy could be expected to be improved on the average about two and onehalf times.

The process did, however, occasionally cause color changes on pyroxylin book covers, noticeably changed the color of leather, and occasionally caused groundwood papers to show visible yellowing. The process did not work equally well on every paper nor, unfortunately, did it strengthen paper that had already deteriorated. A capital investment in equipment would, of course, be required. ${ }^{20}$

In May 1977, just before the field trial ended, CLR and NEH gathered a group of scientists, librarians, and conservationists to study the safety and efficacy of the process and consider where and how it should best be used. At the same time, the Library of Congress' Preservation and Testing Office tested the process extensively and generally corroborated the findings of the lengthy and thorough testing previously carried out by the Barrow Laboratory.

The NEH-CLR review panel recommended further testing on the question of whether the morpholine process presented a health hazard to library patrons or staff. In response, a check with the National Institute for Occupational Safety and Health indicated that this agency did not consider morpholine a carcinogen. To further corroborate this point, samples of morpholinetreated book paper were sent to Litton Bionetics, Inc., to be tested using the Ames mutagenicity technique, which showed a negative response, i.e., no evidence of carcinogenic or mutagenic property. Finally, on the question of whether it was likely that the known carcinogen nitrosomorpholine would be formed in significant amounts through the combining of morpholine in treated books with oxides of nitrogen found in polluted air, an opinion was sought from Dr. Robert Taylor, associate chairman of the Department of Chemistry at the University of Michigan and a CLR consultant on the Barrow project. Based on his investigation, Dr. Taylor concluded that the likelihood of this occurrence "is extremely low and the hazard negligible." 21 
Throughout the development of the morpholine deacidification process, the council had been in close touch with the Research Corporation, a nonprofit foundation for the advancement of science and technology that makes new inventions available in the public interest. Research Corporation took over the patenting and licensing of the process and in August 1979 announced that the first license had been granted to the Pacific Northwest Conservation Laboratory of Port Orchard, Washington.

While the work on the morpholine process was proceeding, Barrow Laboratory staff engaged in other investigations. Under a contract with the Library of Congress, the laboratory reviewed the specifications for permanent/durable paper originally established by W. J. Barrow in 1960 . The review took into account the changes in manufacturing and technology during the period and resulted in revised specifications. Several existing commercial papers, it was shown, could readily meet them. ${ }^{22}$

Other work included investigations of the effects of storage humidity and temperature on paper, improvement of the equipment for testing fold endurance, and continued testing of various kinds of paper for characteristics of permanence and durability. Just before the laboratory closed, plans had been laid for a project to look for a vapor-phase method of strengthening paper.

The council's relationship with the W. J. Barrow Research Laboratory was described by Verner Clapp as that of "a full, if a junior partner." 23 The council "proposed topics for research, ... . followed the reports in detail, ... made suggestions for improvements, alternative approaches, etc." He described this "climate of active collaboration on a matter of mutual concern and excitement" as rewarding, and history has shown it to be of profit to libraries as well. When Clapp died on June 15, 1972, his role with regard to the laboratory was assumed by CLR program officer Carl M. Spaulding, who continued a careful oversight of laboratory activities. Periodically, review groups were assembled to evaluate the laboratory's work and to assist in the setting of future goals and priorities. Such a group assembled in 1973 recommended the continuance of the laboratory, which it be- lieved had been a good investment as well as being unique among organizations working in the conservation field. But it recognized that the laboratory was handicapped by its relative intellectual and geographic isolation from the scientific and library communities and recommended that the council explore alternatives to the laboratory as it was presently constituted and sited. In particular, it was recommended that the laboratory be reestablished on a university campus, where contact with the related sciences and technologies and with a large library would be possible.

However, the council was beginning to recognize that the expense of operating an independent laboratory was growing and inhibiting the council's ability to respond to other equally pressing problems. Although the council approved further support for the laboratory, it did so in the hope that the additional funds for its continuation could be found elsewhere.

As noted earlier, funds were secured from the National Endowment for the Humanities for a project involving largescale testing of the morpholine process. Prospects for other funding, however, were not good, nor was it likely that the laboratory could be relocated easily. Then, just as the large-scale testing was drawing to a close, Dr. Walker, the laboratory's director, suddenly died. With this combination of events, the council regretfully concluded that in view of its "many obligations to libraries and its own funding situation, and because of the increasing costs of the independent laboratory, it could no longer be supported." 24 Following the discontinuance of CLR funding, the Barrow family decided to shut down the laboratory, and much of the specialized equipment was placed on indefinite loan at the Carnegie-Mellon Institute of Research, Carnegie-Mellon University, where it was to be used in the institute's planned research program on paper preservation.

From 1957 to 1977, CLR appropriated both directly and indirectly through the Virginia State Library more than $\$ 1.67$ million in grants in support of the work performed by W. J. Barrow and subsequently the laboratory that bore his name. The accomplishments for this investment were many. The 
principal causes of paper deterioration were identified and documented; permanent/ durable paper and card stock were created and continue to be available commercially; attention to this problem, spotlighted by Barrow's work, contributed to a growing availability of acid-free papers in the United States and Great Britain; testing equipment (e.g., universal book tester, openability plate) was developed and made available and other equipment improved; specifications for permanent/durable paper and standards for binding were promulgated; a mass deacidification process was devised and tested; and a series of publications drew attention to the problems of preservation and assisted many to an understanding of their nature and possibilities for solution.

\section{ALA's Library}

\section{Technology Project}

The establishment and operation of the Barrow Laboratory commanded much of the attention and resources of the council. But in the area of preservation, as in other areas, CLR has consistently sought a variety of mechanisms to attack the basic problems and has attempted to coordinate several different approaches. An example of this is the work performed by the laboratory under contract with the Library Technology Project (LTP) of the American Library Association, also funded by CLR. The project's activities, however, were not restricted to preservation, nor were its preservation activities always connected with Barrow.

When the council approved the establishment of the ALA Library Technology Project in 1959, four principal goals were stated:

1. To improve the quality of library equipment, supplies, and systems.

2. To save money expended on inferior products or systems.

3. To save inordinate expenditure of time in ascertaining existing knowledge on these matters.

4. To produce knowledge where now there is none.

The council provided administrative funds for the project, but it required that separate proposals be made for testing programs, each of which would be evaluated on its merits.
Between 1959 and 1973, LTP engaged in a number of preservation-related projects. Several involved the testing of supplies used by conservators, including pressuresensitive tapes used in the repair and marking of books, polyvinyl acetate adhesives used in mending, laminating equipment, and film coatings and rejuvenation treatments designed to improve the resistance of microfilm to scratching and abrasions caused by use. The tests were usually conducted under contract with both commercial and nonprofit laboratories, such as Barrow or the Chicago Paper Testing laboratories, and the results were published in the official ALA journal.

In addition to testing various products, LTP also attempted to improve what was available. Under contract with the Barrow Laboratory, for example, specifications were developed for a permanent/durable card stock, which would add to the longevity of the millions of catalog cards filed by the nation's libraries on a daily basis. In 1961, with the assistance of the Institute of Paper Chemistry and on behalf of the Public Archives Commission of the state of Delaware, LTP attempted to develop specifications for cardboard stock for manuscript boxes that would make them more suitable for library and archival use in terms of reduced acidity, insect repellency, and fire and moisture resistance. Unlike the former project, where successful commercial runs of a suitable card stock were made, the emphasis in the latter project was on treatments of existing stocks. While it was found possible to build each characteristic into the board, the cost was considered excessive for practical use.

In 1960, with the cosponsorship of the Special Libraries Association (SLA), LTP embarked on a six-year project to develop performance standards for library bindings, which, in many cases, deteriorate faster than the papers they encase. Although specifications had existed since the 1930s for class A library bindings and were amended from time to time, they were considered to be inadequate for two reasons. First, they did not satisfy all of the binding requirements in libraries (e.g., heavily used as opposed to lesser-used materials), and second, they concentrated far too much on 
existing and available equipment, materials, and methods and said too little in terms of prospective use and performance.

Five categories of needed bindings were established through the use of an extensive survey. LTP then contracted with the Barrow Laboratory to develop the necessary tests and equipment that would measure performance. In addition, nearly fifty libraries participated in field tests of trade edition, children's, and class A bindings to allow for a comparison of actual use with machine-produced "use." Finally, three "provisional" performance standards-for durability, workmanship, and openabilitywere published and approved in 1967 by both ALA and SLA and subsequently by the Library Binding Institute. The universal book tester and openability plate developed by the Barrow Laboratory were made available through the Chicago Paper Testing Laboratory, where they are still in active use, primarily in response to requests from publishers.

For librarians responsible for, but unskilled in, the techniques of conservation, perhaps the most useful of the CLR-funded LTP projects was its publication series on the conservation of library materials. Originally planned as an extensive series that would provide a complete manual on the preservation of print and nonprint materials, only two volumes eventually found their way into print, but they have become classics on a conservator's bookshelf. Carolyn Horton's Cleaning and Preserving Binding and Related Materials (second edition, 1969) and Bernard C. Middleton's Restoration of Leather Bindings (1972) provide clear explanations of processes and techniques, accompanied by plentiful line drawings and some photographs. And both were printed on Permalife paper.

The Library Technology Program, as it had come to be known, was discontinued as a separate ALA unit in 1973 when council funding came to an end. Of the more than $\$ 2$ million that had been supplied by CLR for support of the program, $\$ 212,000$ was authorized for investigations relating to the preservation of library collections. ALA continues to supply much-needed evaluative information to libraries concerning equipment, furnishings, automated systems, and supplies through its publication Library Technology Reports.

\section{The Chicago Process}

The work of the Barrow Laboratory and the preservation projects of the Library Technology Program provided much valuable information to the library community. In 1966 a third opportunity arose for yet another approach to solving the problem of paper deterioration by reducing its acidity, this one proposed by a doctoral student studying at the Graduate Library School of the University of Chicago: Richard D. Smith. Smith's investigation was directed at the nonaqueous deacidification of whole books, and the result was dubbed by Smith as the "Chicago process." 25 By the time the grant period ended in 1970, Smith had developed a procedure for treating single sheets of paper using magnesium methoxide. He eventually marketed the solution commercially under the name Wei T'o.

\section{Library of Congress Preservation Office}

A fourth opportunity to assist laboratory investigations into the problems of preservation arose when in 1969 the council received a proposal from the Library of Congress requesting assistance in establishing a preservation research and testing facility. According to the proposal, the new preservation laboratory would "function at the national level and in the national interest to identify, assign priorities to, and conduct research on preservation problems related to books, manuscripts, prints and photographs, maps, microfilms, and other forms of microreproductions, and all other materials which must be preserved by libraries and archives if recorded knowledge is to be available for future generations. ..." The council agreed to provide funds to equip the laboratory and to assist in the review of a proposed research program.

During the grant period, which ran from 1971 to 1975 , the library's preservation laboratory staff embarked on a number of investigations, which included an evaluation of known deacidification methods and development of additional ones, stain identification and removal, measurement of folding endurance and tensile strength of paper, 
use of graft polymerization methods for strengthening deteriorated paper, and unusual methods of drying books. In addition, the laboratory began work on a vapor-phase deacidification method that utilized diethyl zinc vapor for treatment of books in bulk. Testing of this substance is still taking place. Results have been good in terms of neutralizing paper acidity and leaving an alkaline reserve to combat later acid attacks, but care must be taken with the substance because it is pyrophoric.

\section{New England}

\section{Document Conservation Center}

Funding the laboratory efforts of William J. Barrow and the Library of Congress was attractive to the council for several reasons. First of all, both operations concentrated on projects of primary interest to libraries and archives, rather than to commercial, industrial, or other interests. Furthermore, both organizations showed promise of having an impact on the library world at large, rather than concentrating on the preservation of the collection of a single institution. In 1972 another opportunity with much the same characteristics appeared. The state librarians of six New England states approached the council with a request for funding, as part of their Interstate Library Compact, the first regional conservation center. The states were willing to put up half of the initial money to get the operation off the ground. Impressed by this commitment and intrigued by the collaborative and regional aspects of the proposal, the council agreed to match the amount. Thus the New England (now Northeast) Document Conservation Center was born and, within the two-year grant period, became self-supporting.

The center has lived up to its early promise. It annually provides workshop services to about three hundred institutions and reaches another thousand through a conservation seminar program. In addition to the restoration of books, prints, maps, broadsides, manuscripts, and similar documentary materials brought to the center by libraries, archives, historical associations, businesses, museums, and others, the center has set up programs involving conservation of photographs and preservation microfilming and provides a disaster- assistance service to institutions in the region.

\section{Florence Flood}

In 1966 a natural disaster stimulated a series of CLR research grants relating to preservation. The city of Florence, Italy, was inundated by a massive flood. According to a knowledgeable observer, more than $1,200,000$ bibliographic items stored in the basement and ground floor of the Biblioteca Nazionale Centrale di Firenze (BCNF) were damaged, but more than 80 percent were considered salvageable.

The size of the effort required was enormous. "It took human chains of library personnel and student volunteers from all over the world about six weeks just to extract the books from the mud," reported the observer. Fortunately, many nations joined in the restoration work and donated equipment, the time of professional conservators and technicians, and funds for operations. The council also contributed to the effort by funding several proposals for research designed to assist BCNF efforts and to disseminate the techniques used in the Italian national library's restoration department.

In 1968, a grant was awarded to the Imperial College of Science and Technology for investigations of the scientific aspects of conservation, particularly needed with regard to work on the valuable pre-1840 books contained in the BCNF's Magliabechi and Palatine collections. Although work was begun on the bleaching and washing of documents, on the use of heat-set mending tissues, and on limp-vellum binding practices, the project unfortunately became embroiled in an administrative tangle and eventually was disbanded.

Two of the participants, however, received separate grants to continue aspects of the work that had shown particular promise. Christopher Clarkson, an English bookbinder, completed a study of early European limp-vellum binding practices and showed in great detail the process of limp-vellum binding. Margaret Hey, an English chemist, moved to Rome in 1971 to continue her work on bleaching and heat-set paper mending tissues, financed in part by CLR, at the Instituto di Patologia del Libro.

At about the same time, Anthony G. 
Cains, a British restoration expert who had been appointed technical director of restoration at the BCNF in 1967, successfully sought support from the council to complete work on a manual of the restoration techniques for printed books and parchment manuscripts used at the library. The council received a draft of the work in 1972 and noted that it included some of the results achieved by both Clarkson and Hey. In 1974, Paul N. Banks, conservator at the Newberry Library, also received a small CLR grant to assist him in writing a manual on library conservation. Neither effort has yet reached publication.

\section{Aids for Conservators}

The council's support of these manuals serves as an example of another area of CLR interest within the field of preservation. Occasionally over the years circumstances have allowed the council to assist in the preparation of publications that have the potential of serving the needs of a large number of libraries, archives, historical associations, and other institutions concerned with conservation of cultural properties. In the 1960s, for example, with the cooperation of the National Science Foundation, the council was able to arrange for the translation and publication of several volumes of Russian studies in the preservation of documents and books. The Englishlanguage editions were prepared by the Israel Program for Scientific Translations for the U.S. Department of Commerce and were distributed by that agency. ${ }^{26}$

In the 1970s, the American Association for State and Local History (AASLH) sought CLR assistance for the preparation of two volumes directed to persons and institutions entrusted with the care of manuscripts and historical photographs. Kenneth W. Duckett's Modern Manuscripts: A Practical Manual for Their Management, Care, and Use (Nashville, Tenn.: AASLH, 1975) was well received and won the 1976 Waldo Gifford Leland prize, given annually by the Society of American Archivists for the best addition to the professional archival literature. In 1977, the AASLH's handsomely illustrated Collection, Use, and Care of Historical Photographs, by Robert A. Wein- stein and Larry Booth (Nashville, Tenn.: AASLH, 1977), was also published to wide professional acclaim.

\section{National Planning}

The work of Barrow and others revealed that the book stacks of libraries contained something in the nature of a time bomb. Acid, compounded by growing environmental pollution, was eating away the records of history at a rapid rate. Advances in microform technology and research into other means of preservation were beginning to point the way to technical solutions. But in terms of the total collection needing treatment, the problem was quickly seen to be of elephantine proportions, much out of the reach of an individual institution. Although cooperative programs are now seen as the answer to many of the difficulties of libraries, they have always been regarded as a necessity in the area of preservation. Yet to date they have proved almost impossible to achieve.

Microfilming has for years been regarded as the most promising means of preserving the intellectual content of deteriorating publications, and it is in this area that the first major cooperative efforts began. Newspapers, invariably printed on fast-decaying groundwood paper, were the most serious problem and thus became the first target in 1938 when Harvard University received a grant from the Rockefeller Foundation to reproduce on microfilm files of foreign newspapers. ${ }^{27}$ Recognizing the need to avoid wasteful duplication of limited resources, the Library of Congress set up a microfilm clearinghouse for information about proposed, in-progress, and completed microfilming projects and began to publish union lists of newspapers already microfilmed and lists of newspapers recommended for this treatment. The Association of Research Libraries played a role in much of the planning of these activities. Recognizing the need for expanded coverage of foreign newspapers and of national coordination of such projects, ARL established in 1956 a foreign newspaper microfilm project administered by the Mid-West Interlibrary Center (which eventually became the Center for Research Libraries). Four years later, the 
Council on Library Resources entered the picture.

\section{Association of Research Libraries}

Three considerations led ARL to conclude that something had to be done about microforms. First, improvement in technology had made it easy to make microcopies of any kind of textual material. Second, for preservation purposes, microform was thought to be more permanent than paper. Third, publishers were beginning to produce original publications in microform. Bibliographic control of microforms was practically nonexistent. No systematic procedure for the reporting of microform projects by their producers existed, nor were there means for libraries to report, for use by others, their catalog entries of individual titles on microform.

In 1960, therefore, ARL sought funds from the council for a study by Wesley Simonton, a professor in the Library School of the University of Minnesota, for the pur* pose of developing, with the cooperation of scholars, librarians, and producers of microfilms, a comprehensive mechanism for bringing scholarly material in microform under bibliographic control. ARL was not alone in its concern, for it had been urged to sponsor the study by the American Historical Association's Committee on Documentary Reproduction and the American Library Association's Subcommittee on Micropublishing Projects.

The Simonton study recommended several improvements involving the inclusion of microform publications in general catalogs and union lists of materials in other forms, as well as improvements in filming practices. In addition, it was suggested that a new national listing of master microfilm negatives be established to indicate what materials had been filmed and which master films were available for reproduction. With the help of a subcommitttee within ALA's Resources and Technical Services Division, the National Register of Microform Masters took shape. In January 1965 a CLR grant to ARL established a unit at the Library of Congress for the purpose of producing the first volume of the resister. Published annually since 1966, the edition for 1979 contained sixty thousand entries in approximately one thousand pages. The Library of Congress assumed financial support of the project in 1967.

The Register contained entries for foreign and domestic books, pamphlets, serials, and foreign doctoral dissertations. Newspapers continued to be listed in the LC publication Newspapers on Microfilm. Following the establishment of the ARL foreign newspaper microfilming project in 1956, area studies programs continued to expand and the interest of research libraries in foreign newspapers grew accordingly. Separate microfilming and acquisitions projects began to spring up, again causing problems of duplication and accessibility.

The ARL Foreign Newspaper Microfilm Committee therefore expanded its scope from one of oversight of the ARL project to that of developing a truly national foreign newspaper microfilming program encompassing at least two thousand titles and utilizing the resources of the ARL project, the Library of Congress, and other interested institutions. In May 1969, the council funded a preliminary study for such a program. The report made recommendations concerning the expansion of coverage of foreign newspapers required to serve the scholarly community of the United States and Canada and identified institutions willing and able to participate in a national program. Further, it recommended the creation of a national coordinating office "to facilitate institutional cooperative filming or acquisitions and to facilitate accessibility through interlibrary loan and other means." 28 In 1972 , the position of coordinator of foreign newspaper microfilming was established within the Reference Department of the Library of Congress. In 1976, coordination of domestic newspaper microfilming was added to the position and it was moved administratively to the library's Preservation Office.

ARL's interest in preservation did not end with microfilming programs, however. For one thing, although it was thought that microforms would be more permanent than paper, no data were available to support that assumption. And while the filming itself was easy, it was still too expensive to 


\section{6 / College \& Research Libraries • March 1981}

consider application to an entire library collection.

In 1960, spurred by the information and advances produced by the Barrow Laboratory, ARL appointed a Committee on the Preservation of Research Library Materials with Harvard's librarian, Douglas W. Bryant, as chair, to investigate various aspects of the problem of paper deterioration. At the behest of this group, the council began a series of grants that attempted first to gain some idea of the size of the problem and second to develop a national program for solving it.

The first grant, to Virginia state librarian Randolph W. Church, allowed Church to pursue an investigation that would provide, among other things, data as to the number of books in libraries published in the period from the introduction of mechanicalchemical book papers in the 1860 s through 1960. Church recommended that a sample of the National Union Catalog be taken, which would allow an estimate of total number to be made. Following this advice, CLR awarded a second grant to ARL to contract with the Research Triangle Institute to carry out the sampling, with the hope of establishing by this means a statistical basis for planning the preservation of research library materials. Based on what had been reported to the National Union Catalog, the institute concluded that research libraries contained at least $7,665,800$ separate titles for books (not serials) published after 1869, and that these contained roughly 1.7 billion pages. ${ }^{29}$

The enormity of the problem served as a goad to further action. In 1962, a third CLR grant allowed Gordon Williams to look at methods for (a) coordinating efforts so as to assure maximum utility of results; (b) developing bibliographic control of materials submitted to preservation programs; and (c) developing arrangements for custody and service, in the national interest, of microfilm negatives and other master copies resulting from these programs. Williams' central recommendation was for the establishment of a central preservation agency, federally supported, to preserve one copy of every significant book in its original form (by deacidification and storage at the lowest practical temperatures) and to make microform copies available readily and cheaply to all libraries. Doubts about the longevity of microfilm were expressed, thus the need for preserving at least one copy of an original, and it was shown that it would cost "only about $\$ 2$ more per volume to preserve the original for an indefinitely long future time and make a microfilm copy of it only when the book needs to be used, than it will cost to microfilm the original now and discard the original completely." 30

ARL endorsed the report in January 1965. The prospects looked bright when ARL reported to the council that "the $\mathrm{Li}$ brary of Congress had agreed to accept responsibility for a national program for the preservation of deteriorating books in accordance with the principles set forth in the report. ...." " 31

The Library of Congess had, it turned out, set aside some twenty thousand items that had been pulled from the main collection because they were too brittle to withstand use. Using this collection, the library proposed a pilot project that would develop what it hoped would be inexpensive routines for comparing existing copies of deteriorating works wherever they were located and determining the best copy for preservation, for arranging for appropriate treatment, and for recording the copy's existence so other libraries would not have to repeat the operation. Through ARL, CLR awarded the required funds and the library set to work.

In November 1967, the library reported to ARL that "it is administratively feasible to establish a national preservation collection of materials now deteriorating in the nation's research libraries. This assessment, however, extends only to the identification of brittle or deteriorating materials in other libraries and to a determination of the physical condition of such materials." Actual implementation, the library said, would pose substantial technical questions as well as administrative problems. The willingness of libraries to contribute to a national preservation collection had not been ascertained, nor was it known whether they would be willing to accept responsibility for preserving books for which a given library was listed as holder of a national preservation copy. Nor, as the Librarian of Congess pointed out in his covering letter, was the 
procedural process inexpensive. ${ }^{32}$

In the early 1970 s, ARL again tried to spell out a practical national strategy for preservation, this time under the auspices of a grant from the U.S. Office of Education. The final report stated that the study was prompted by "the assumption that the general plan incorporated in the 1964 report needed only the addition of operational details and funding for implementation." ${ }_{33}$ Views had changed, the author acknowledged, and even though the original objectives were still valid, six years had passed with no action. A problem of scale was involved.

In moving from research and training to the topic of actual operating programs in libraries, the complexity of the preservation problem becomes apparent. In a sense, it is as if there were two preservation problems, one reducible to specific items or specific categories of material in individual research collections; the other a seemingly unscalable mountain of the millions of volumes in the slowly crumbling collections of older research libraries of the country. In the first case, there is some action and perhaps even progress. Logic would suggest that such progress would lead to improvement in the second case as well, but the change in scale from the first situation to the second seems somehow to undermine the possibility of even a fleeting sense of accomplishment. $^{34}$

To bring the problem down to manageable size, the report includes a number of suggestions for action in the areas of research and education and training. In terms of collective action, however, the proposal shifted from the earlier call for a centralized preservation collection to the idea of a national system of collections. As a first step, it was suggested that ten or fifteen libraries join in a "preservation consortium" to carry out certain specific preservation projects. This would set the stage for the formulation of common preservation procedures and uniform performance standards. Local preservation collections would become the basis for national resources collections, which would result in a shared responsibility. Eventually, a national library corporation might act as the coordinator for the national program. "By not aspiring to preserve everything and concentrating instead on discrete subject areas, some real progress becomes possible," the report concluded. ${ }^{35}$

For all its advances in other areas, at this time technology for preservation had not, it seemed, caught up with the national planning. No efficient, inexpensive method for deacidifying books in bulk had been invented. Optimum economical storage conditions were as yet unknown. Procedures and standards for bibliographic control were still unformulated. Work was proceeding on these items, and until information became available, it appeared that the political and economic questions raised by the LC Brittle Book Project and the collective action suggested by ARL could not be addressed. To this point, CLR had expended approximately $\$ 103,000$ for work leading toward a national preservation program. Action was, however, temporarily halted.

\section{Library of Congress}

As noted earlier, in 1969 the Library of Congress turned its attention to setting up a preservation laboratory, which, in a program of research, would investigate some of the problems that seemed to prevent the building of a coherent national plan. By 1976 , with considerable progress made in its own program, LC announced to the American Library Association at its annual conference that it was now prepared to begin the development of a broad-scale national program. The first step was an invitational conference, held in December 1976 , the purpose of which was to obtain opinions and recommendations of the library and archival communities on a proposed program. Council funds supported the event.

The library's plan called for a series of actions grouped in three broad categories. First, to preserve those items the intellectual content of which does not warrant more expensive treatment, it proposed a national preservation microfilming center with space for archival storage of master negatives, along with appropriate surveys, standards development, bibliographic control mechanisms, and other procedures that would allow for contributions to the center and retrieval of the items housed within. For those items that ought to be preserved in the original format, the plan proposed a training pro- 
gram for conservators, establishment of regional conservation centers and emergency salvage teams, and an improved means of sharing information through national conservation workshops and distribution of training aids. Finally, to ensure that the materials of the future do not follow the route to decay of their forebears, the library recommended provision of low-temperature facilities and microfilming procedures and an effort to persuade papermakers to produce stronger, long-lived paper.

Although the wide-ranging discussion made clear the divergence of opinion on the best way to proceed, the need for action was strongly felt. Warren J. Haas, at that time vice-president and university librarian at Columbia University, closed the conference by saying that "scholars, librarians and archivists do, in fact, have the responsibility to solve this preservation problem. And that responsibility is not conditional-it does not depend on public perception, or amount of money, or anything else. It is our responsibility, and we can either succeed or fail. The rate at which things get done is a function of money; whether or not they are done at all is a function of people." ${ }^{36} \mathrm{He}$ called for the establishment of a small advisory committee to begin the process of determining a course of action. The Council on Library Resources, he said, would support the meeting expenses of such a group.

The Library of Congress thereupon established an ad hoc Advisory Committee for a National Preservation Program and on June 14, 1977, announced the appointment of a national preservation program officer to coordinate LC's activities. Only two meetings of the committee were held, in June and September of 1977. The group considered the list of possible projects and recommended priorities. At the top of the list were the items considered easiest of accomplishment: timely preparation of LC publications on preservation, LC sponsorship of a series of workshops and seminars, the development of three-month conservation institutes, and production of a series of conservation training aids. At its second meeting the committee unanimously recommended that LC move to convert the $\mathrm{Na}$ tional Register of Microform Masters to machine-readable form and went on record as favoring the training of more conservators. The group also asked the national preservation program officer to investigate the topic of a cold-storage facility.

Just six months after the initial appointment, the position of national preservation program officer was vacated and has not been refilled. To be sure, the library has continued to operate a National Preservation Program Office, which most recently has issued a newsletter called National Preservation Report. The results of LC's research and testing program, directed at problems associated with its own collections, are often useful to all libraries. LC has continued to publish pamphlets containing valuable basic information on conservation techniques, and its staff frequently conduct workshops, make presentations, and consult on problems caused by natural disasters. Some materials used in conservation have been made available commercially after careful testing and experimentation in LC laboratories. The library has been spending $\$ 1$ million a year each on preservation microfilming and binding. These activities are valuable in themselves. However, no other action on any of the committee's recommendations has been reported. In the last few years, the library also has entered into a period of budget constraint. In the face of the demanding job of preserving its own collections, and for a number of internal, fiscal, and political reasons, the library has been unable to assume the leadership role it had announced.

\section{Current Prospects}

Although a lack of fiscal resources and technical procedures, along with a lack of trained manpower, has adversely affected development of a national strategy for preservation, the current lack of leadership and the failure by librarians to assume responsibility are perhaps the most serious impediments to progress. Plainly speaking, academic and research libraries, whose collections comprise the cultural record and which therefore are the most threatened, have historically shown little capacity for collective action. Many important projects have salvaged, and continue to salvage, substantial pieces of the records of history. But 
deterioration is occurring at a faster rate than conservation, and the threat that, as one commentator put it, the nineteenth century might become known as "the beginning of the bookless age" remains. Yet events of recent years have engendered hope, rather than despair, for two reasons: a growing awareness of the seriousness of the problem, and a remarkable shift in attitude among academic and research libraries. Advances in technology are also playing a role.

That the message is getting across was clearly documented by Pamela Darling in a recent issue of Library Journal in which she cataloged the association meeting programs, courses, institutes, workshops, articles in journals within and outside the profession, and publications that have blossomed since 1976. ${ }^{37}$ The problem of manpower is being seriously addressed by, among others, Columbia University's School of Library Service, which is seeking to fund and develop a full-scale academic program for conservators and preservation program administrators. The Resources and Technical Services Division of the American Library Association has created a Preservation of Library Materials Section. But general awareness does not create the capacity for action.

In 1974, four major research libraries -Columbia, Yale, Harvard, and the New York Public Library-formed the Research Libraries Group. Although Harvard withdrew, the group has since enlarged to more than twenty members. Dedicated to "improving the management of the information resources necessary for the advancement of scholarship," the group is an effort "to manage the transition from locally self-sufficient and independent comprehensive collections to a nationwide system of interdependencies that will preserve and enhance our national capacity for serious research in all fields of knowledge and improve our ability to locate and retrieve relevant information." 38 The formation of this group signals a shift in attitude of many research libraries from one of waiting for a savior to one of self-help. And it is this group that may, at last, provide the capacity for joint action.

Why is this group a promising locus for activity? For one thing, RLG members are connected by a fully functioning comput- erized bibliographic data base, capable of refinement to add the necessary information concerning preservation on an item-by-item basis. Second, the group has been committed from the beginning to the goals of shared resources and cooperative collection development, and preservation is a large factor in both. Third, the group is not waiting for the Library of Congress to take the lead, but views LC as an important partner in reaching its goals. The potential for concerted action clearly is evident.

Nor is the group alone. The Association of Research Libraries is continuing to initiate activities that will assist the preservation cause. Most recently, with the help of an NEH grant, ARL commissioned another study of the bibliographic control of materials in microforms. While gains had been made following the Simonton study, changes in cataloging rules and the growth of machine-readable data bases had made it appropriate to reassess the situation. ARL's objective is "to plan and coordinate North American efforts toward building a machinereadable data base of cataloging records for materials in microform," with particular emphasis given "to facilitating the production and dissemination of analytics for titles published in large microform sets." ${ }^{39} \mathrm{ARL}$ is involving librarians, microform publishers, representatives of bibliographic utilities, and others to develop the agreements, standards, methods, and mechanisms required. In addition, the ARL Office of Management Studies also received a grant from NEH to develop a self-study process that will enable individual institutions to focus on preservation and its relationships to library processes from a management point of view.

There are other movements as well: At a meeting in June 1980 at Snowbird, Utah, representatives from libraries, archives, historical societies, and museums in eighteen western states agreed on a master plan for preservation and conservation of materials in the West. The plan included, among other items, the creation of a regional conservation clearinghouse in the short term and in the long term, the development of a regional capacity to treat deteriorating materials.

Increased funding possibilities in both federal and private sectors are also playing 
a role. The National Endowment for the Humanities has been mentioned several times as providing funding support for preservation projects, and there is evidence of increased interest. NEH's fiscal year 1981 budget carries a line item specifically earmarked for preservation. The Department of Education, through Title II-C of the Higher Education Act, has awarded more than $\$ 3$ million since 1978 to research libraries for substantial preservation programs. With these funds the Art Institute of Chicago is preserving rare architecture photogravure plates, Harvard is making master microfilm negatives of, among other items, Chinese ephemera, and the University of Alaska is preserving deteriorating materials in its Alaskan and Polar Region Collection. The records program of the National Historical Publications and Records Commission, established in 1974, has pumped additional money into programs for preserving and making accessible valuable archival collections. Several private foundations, notably the Andrew W. Mellon Foundation, have shown increased interest in assessing efforts toward preservation. Already the Mellon Foundation has awarded $\$ 750,000$ to the New York Public Library, which has had a strong institutional preservation program for years, to develop an on-line data base of microform masters and micropreservation activity. It will be made available to other libraries through the Research Libraries Group.

The council has not been idle, either, in pressing the cause of preservation and in responding to promising programs. A change in the council's funding pattern has limited the resources available for programs in this area, but it has not lessened its interest or concern. CLR has never been able to respond to the needs of individual institutions for preservation of their local collections, nor has it been able to finance large-scale cooperative projects. As in the past, the council looks for programs with multiplier effects.

One example, if it ever comes to pass, would be the establishment of a National Periodicals Center (NPC). The council was involved in the early planning stages of the proposed center. In 1977 at the request of the Library of Congress, CLR began the preparation of a technical development plan that outlined the key operating characteristics, requirements, and funding needed to establish such an institution. A primary objective of the NPC, according to the plan, is its potential contribution to the preservation of periodical material. Its centralized collection of $30,000-60,000$ journals would be preserved in perpetuity and its preservation activities would become "an integral and dependable part of a national preservation program." 40 Following publication of the plan in 1978, legislation was introduced into the U.S. Congress to continue the planning for the center.

At the present time, several modest CLR-supported projects focus on a number of aspects of the preservation issue. Early in 1980, CLR joined other funding agents in support of the Library Affairs Conservation Program at Southern Illinois University, Carbondale. The university library has set up a conservation laboratory, headed by a trained conservator, and is developing training programs, workshops, and other activities to assist libraries and other institutions throughout Illinois and the region. In a similar vein, to promote increased awareness of preservation activities and opportunities, CLR awarded a small two-year grant to the University of Wyoming to support direct editorial costs associated with producing the fledgling newsletter Conservation Administration News, edited by the university's library director.

To consider the preservation issue fully, however, one must, like Janus, look in opposite directions. Because the retrospective side of the issue is so enormous, it is easy to fail to look ahead to the prospective problem. If steps are not taken to change the way books are made, the retrospective problem becomes exponentially more serious.

As mentioned earlier, an outcry in the 1960s accompanied the reports by Barrow on the extent of the deterioration of library materials and his concurrent discovery that it was possible technically to make a permanent/durable paper at affordable prices. Following the 1960 conference, journal articles and letters to the editor began to call on paper manufacturers to produce acid-free papers and publishers to use them. In 1964, 
the University of Oklahoma Press announced its intention of indicating in each book the life expectancy of the paper used. In 1968 an editorial in Publishers Weekly reported two promising trends. ${ }^{41}$ At least two paper mills had converted to acid-free processes and the McGraw-Hill Company announced that it would print all of its books on alkaline stock. Although the ALA Joint Committee on Permanent/Durable Paper proved ineffectual, in 1967 another joint committee, this time of the American Book Publishers Council and ALA's Resources and Technical Services Division, brought up the matter again and sent out a questionnaire to ascertain the extent of use of the paper among publishers. But by 1970 , the hue and cry, such as it was, seemed again to die down. A shortage of supply of paper in the late 1970s did not help revive general interest.

In his Bowker Memorial Lecture in November 1977, Herbert S. Bailey, Jr., pointed once again to the need for heightened awareness among publishers of the problem of paper permanence. The fact that there has been some improvement in paper-manufacturing processes and in the number of alkaline mills has, he said, perhaps caused the problem to be forgotten. "In a recent study it was found that most publishers' production managers did not know whether they were using permanent/durable paper," he reported. "Their minds were on other things such as appearance, printability, opacity, texture, bulk, and price." ${ }_{42}$ To help remind publishers and ensure the longevity of the works it sponsors, the National Historical Publications and Records Commission in 1978 issued standards that must be met by papers used in NHPRC publications. By 1979 , with interest in the preservation issue again mounting, the time seemed right to attack the prospective aspects once more.

On May 14, 1979, CLR and the Andrew W. Mellon Foundation invited about twenty individuals with knowledge of paper manufacturing, publishing, and library book preservation to contribute to a discussion in New York. The participants sought to gather information about book paper and its use and to identify ways to address the prospective aspects of the preservation problem. Following that meeting, a Committee on Production Guidelines for Book Longevity was formed to carry on the discussion and plan a program of action. The committee determined that its aim was to establish a basic set of guidelines to assure reasonable permanence and acceptable durability and to consider the relation of the guidelines to the ways in which books are used. In essence, the committee is again seeking to raise awareness of the prospective problem among all those concerned and to develop practical, realistic methods of dealing with it. The report of the committee was expected in late 1980 .

The problem of preservation transcends national borders, of course. In an attempt to focus attention at an international level, the council awarded funds to the International Federation of Library Associations and Institutions (IFLA) for several projects, among them an examination of the problems associated with prospective preservation. IFLA will seek to give preservation greater visibility and will address such questions as whether special manufacturing of library copies should be advocated and what will be the role of microforms in preserving materials for future use. The special climatic conditions to which paper is exposed in Third World countries will also be studied. At an international conference in Bellagio, Italy, in May 1980, the International Council on Archives agreed to participate in the IFLA venture.

But there is more, much more, to be done. Although two processes for mass deacidification of books have been developed, one is still in the laboratory phase and the other, while available commercially, has received little attention. Recent developments in computer technology and the emergence of videodiscs and their storage capabilities have led to the question of whether there are suitable applications of these technologies for preservation purposes. Columbia University's projected training program certainly will not be able to supply the total number of specialists needed to address the preservation problems of individual institutions. And while there is substantial movement toward developing the capacity for collective action, and an apparent increase in funding pros- 
pects, there still is no national program or system for preservation.

The council will continue to monitor events in this crucial area and, within its limited resources, to supply funding for projects that hold promise of progress toward solutions. When it can act as a catalyst in helping to identify and clarify the issues at stake or coordinate disparate activities, it will. But in the end, commitment and responsibility for leadership must be assumed by those who have custody of the collections, with assistance from scholars, university officials, publishers, papermakers, and others engaged in creating and using the records of humankind.

\section{REFERENCES}

1. James W. Henderson, "Foreword," in John P. Baker and Marguerite C. Soroka, eds., Library Conservation: Preservation in Perspective (Stroudsburg, Pa.: Dowden, Hutchinson \& Ross, 1978), p.vi.

2. Edwin E. Williams, "Deterioration of Library Collections Today," in John P. Baker and Marguerite C. Soroka, eds., Library Conservation: Preservation in Perspective (Stroudsburg, Pa.: Dowden, Hutchinson \& Ross, 1978) p. 18.

3. Verner W. Clapp to Bernard G. Barrow, Aug. 19, 1968, Project Files, Council on Library Resources, Washington, D.C. Also, in 1948, this entry appears in Clapp's diary: "Bill Barrows [sic] wants a grant for research in old paper," Diaries of Verner W. Clapp, Clapp Papers, Library of Congress, Washington, D.C.

4. Randolph W. Church, "Is There a Doctor in the House?" Publishers Weekly 175:76 Jan. $5,1959)$.

5. Randolph W. Church, ed., Deterioration of Book Stock, Causes and Remedies: Two Studies on the Permanence of Paper (Richmond, Va.: Virginia State Library, 1959), p.16.

6. W. J. Barrow and Reavis C. Sproull, "Permanence in Book Papers," Science 129:1079 (1959).

7. A useful discussion of the history of papermaking and the effects of technological processes on durability is found in Verner W. Clapp, "The Story of Permanent/Durable Book-Paper, 1115-1970," Scholarly Publishing 2:107-24, 229-45, 353-67 (1971).

8. W. J. Barrow Research Laboratory, Strength and Other Characteristics of Book Papers, 1800-1899 (Permanence/Durability of the Book, no.5 [Richmond, Va.: The Author, 1967]).

9. Randolph W. Church, ed., The Manufacture and Testing of Durable Book Papers: Based on the Investigations of W. J. Barrow (Richmond, Va.: Virginia State Library, 1960), p. 23-27.

10. Permanent/Durable Book Paper, summary of a conference held in Washington, D.C.,
Sept. 16, 1960 (Richmond, Va.: Virginia State Library, 1960), p. 15.

11. Lee E. Grove, "Paper Deterioration-An Old Story," College \& Research Libraries 25:365 (1964).

12. Permanent/Durable Book Paper, p.28.

13. Randolph W. Church to ALA Joint Committee on Permanent/Durable Paper, Feb. 5, 1962, Verner W. Clapp Papers, Library of Congress, Washington, D.C.

14. Forrest F. Carhart, Jr., to Fred C. Cole, Sept. 26, 1968, Project Files, Council on Library Resources, Washington, D.C.

15. Council on Library Resources, 13th Annual Report (Washington, D.C.: The Council, 1969), p. 35.

16. W. J. Barrow to Verner W. Clapp, Aug. 16, 1967, Project Files, Council on Library Resources, Washington, D.C.

17. Leo Friedman, director, Division of Pharmacology and Toxicology, Food and Drug Administration, to R. N. Dupuis, Nov. 28, 1969, Project Files, Council on Library Resources, Washington, D.C.

18. Arno Roessler to R. N. Dupuis, Sept. 2, 1970, Project Files, Council on Library Resources, Washington, D.C.

19. Minutes of meeting on program of W. J. Barrow Research Laboratory, July 29, 1969 , Project Files, Council on Library Resources, Washington, D.C.

20. Bernard F. Walker, "Morpholine Deacidification of Whole Books," in John C. Williams, ed., Preservation of Paper and Textiles of Historic and Artistic Value (Washington, D.C.: American Chemical Society, 1977), p. 85-86.

21. Robert C. Taylor to Carl M. Spaulding, July 11, 1977, Project Files, Council on Library Resources, Washington, D.C.

22. Barrow Research Laboratory, "Specifications for Permanent/Durable Book Papers," in Clark W. Nelson, ed., "Technical Notes," American Archivist 38:405-16 (1975).

23. Clapp to B. G. Barrow, Aug. 19, 1968, Project Files, Council on Library Resources, Washington, D.C. 
24. Council on Library Resources, 21st Annual Report (Washington D.C.: The Council, 1977), p.45.

25. Richard D. Smith, "New Approaches to Preservation," Library Quarterly 40:143 (1970).

26. Collection of Materials on the Preservation of Library Resources, no.2, ed. L. G. Petrova; no.3, ed. L. A. Belyakova and O. V. Kozulina; tr. from the Russian (Jerusalem: Israel Program for Scientific Translations, 1964); D. M. Flyate, ed., Preservation of Documents and Papers, tr. from the Russian (Jerusalem: Israel Program for Scientific Translations, 1968); New Methods for the Restoration and Preservation of Documents and Books, ed. N. Ya. Solechnik, tr. from the Russian (Jerusalem: Israel Program for Scientific Translations, 1964).

27. For a detailed history of cooperative newspaper microfilming programs, see John Y. Cole, "Developing a National Foreign Newspaper Microfilming Program," Library Resources \& Technical Services 18:5-17 (1974).

28. Norman J. Shaffer, "Study to Develop a National Foreign Newspaper Microfilm Program: Final Report" (Paper presented at the meeting of the Foreign Newspaper Microfilm Committee, Association of Research Libraries, Detroit, June 30, 1970), p. 10-11.

29. Edwin E. Williams, "Magnitude of the Paper Deterioration Problem as Measured by a National Union Catalog Sample," College \& Research Libraries 23:543 (1962).

30. Gordon R. Williams, "The Preservation of Deteriorating Books," Library Journal 91:55 (1966).

31. James E. Skipper to Verner W. Clapp, Jan.
18, 1966, Project Files, Council on Library Resources, Washington, D.C.

32. L. Quincy Mumford to Douglas Bryant, Dec. 14, 1967, Project Files, Council on Library Resources, Washington, D.C.

33. Warren J. Haas, Preparation of Detailed Specifications for a National System for the Preservation of Library Materials, Final Report, Project No. 0-8004, U.S. Office of Education (Washington, D.C.: Association of Research Libraries, 1972), p. 2.

34. Ibid., p.8.

35. Ibid., p. 24.

36. Proceedings of the Planning Conference for a National Preservation Program Held at the Library of Congress in Washington, D.C., on December 16 and 17, 1976 (Washington, D.C.: Library of Congress, 1980), p. 122.

37. Pamela W. Darling, "Preservation: Today on a Shoestring, Tomorrow. . . . ?" Library Journal 105:781-85 (1980).

38. Research Libraries Group, Inc., "An Introduction to the Research Libraries Group, Inc." (Stanford, Calif.: The Group, 1980), p. 1.

39. "Microform Project Underway," Association of Research Libraries Newsletter, no.99:1011 (Nov. 30, 1979).

40. Council on Library Resources, Inc., A Technical Development Plan for a National Periodicals Center (Washington, D.C.: The Council, 1978), p. 15.

41. "More Pleas for Permanent Papers," Publishers Weekly 193:69 (March 4, 1968).

42. Herbert S. Bailey, Jr., The Traditional Book in the Electronic Age (New York: Bowker, 1978), p.17.

\section{Bibliography OF ItEMS RESUlting fROM OR RELATED to CLR-Supported Programs, 1956-80}

Applebaum, Edmond L. "Implications of the National Register of Microform Masters as Part of a National Preservation Program," Library Resources \& Technical Services 9:489-94 (1965).

Auerbach, Sylvia. "Coming: Books That Won't Crumble," Economics and Business Bulletin of the School of Business Administration, Temple University 16:26-28 (March 1964).

Barrow, W. J. "An Accelerated Aging Study of Several Writing Papers: Re-evaluation of Data," TAPPI 47:105-7 (1964).

- "Acidity: An Undesirable Property in Paste and Mending Tissue," American Archivist 30:190-93 (1967).

- "Archival File Folders," American Archivist 28:125-28 (1965).
The Barrow Method of Restoring Deteriorated Documents. Richmond, Va.: Virginia State Library, 1965.

- "Deacidification and Lamination of Deteriorated Documents, 1938-63," American Archivist 28:285-90 (1965).

_. "Establishing Least Squares Regression Lines for Data of Aged Paper," TAPPI 45:209A-10A (1962). Supp.

- "Hot vs. Cold Extraction Methods for Making a pH Determination," TAPPI 46:46872 (1963).

- "New Device Tests Performance of Library Bindings," Book Production 79:60-62 (March 1964).

- Permanence and Durability of Library Catalog Cards. (LTP Publication no.3) Chica- 
go: American Library Assn., Library Technology Project, 1961.

Barrow., W. J., and Carlton, Ann M. "Durability of Three Current Laminating Tissues," American Archivist 30:526-29 (1967).

- "Permanence of Laminating Tissue," American Archivist 31:88-91 (1968).

Barrow, W. J., and Sproull, Reavis C. "Permanence in Book Papers," Science 129:1075-84 (1959).

W. J. Barrow Research Laboratory. Permanence/ Durability of the Book. Richmond, Va.: W. J. Barrow Research Laboratory, 1963-74.

I. A Two-Year Research Program. 1963.

II. Test Data of Naturally Aged Papers . 1964.

III. Spray Deacidification. 1964.

IV. Polyvinyl Acetate (PVA) Adhesives for Use in Library Book-Binding. 1965.

V. Strength and Other Characteristics of Book Papers, 1800-1899. 1967.

VI. Spot Testing for Unstable Modern Book and Record Papers. 1969.

VII. Physical and Chemical Properties of Book Paper, 1507-1949. 1974.

. "Specifications for Permanent/Durable Book Papers," in Clark W. Nelson, ed., "Technical Notes," American Archivist 38:405-16 (1975). Also available from ERIC (ED 104 345).

Blum, Fred. "The National Register of Microfilm [sic] Masters (NRMM)," Microcosm 12:3 (June 1967).

Carhart, Forrest F., Jr. "Performance Standards in Library Binding," Book Production 79:74 (Jan. 1964).

Carlton, Ann M. "Aging of Paper," in Kenneth W. Britt, ed., Handbook of Pulp and Paper Technology, p.709-14. 2d ed. New York: Van Nostrand, 1970.

Church, Randolph W., ed. Deterioration of Book Stock, Causes and Remedies: Two Studies on the Permanence of Paper; conducted by W. J. Barrow. Richmond, Va.: Virginia State Library, 1959.

"Is There a Doctor in the House?" Publishers Weekly 175:76, 78-80 (Jan. 5, 1959). , ed. The Manufacture and Testing of Durable Book Papers; based on the investigations of W. J. Barrow. Richmond, Va.: Virginia State Library, 1960.

. "Perish the Paper, Perish the Book, Perish the Thought: An Inquiry," Publishers Weekly 172:54-58 (Sept. 2, 1957).

Clapp, Verner W. ' 'Permanent/Durable' Book Papers," ALA Bulletin 57:847-52 (1963).

. "Permanent/Durable Book Papers," Book Industry 1:28-31, 52 (Dec. 1964).

"The Story of Permanent/Durable BookPaper, 1115-1970," Scholarly Publishing 2:10724, 229-45, 353-67 (1971).
Collection of Materials on the Preservation of Library Resources; no.2, ed. L. G. Petrova; no.3, ed. L. A. Belyakova and O. V. Kozulina; tr. from the Russian. Published pursuant to an agreement with the National Science Foundation and the Council on Library Resources. Jerusalem: Israel Program for Scientific Translations, 1964.

Cunha, George Martin. "National Trends in Cooperative Approaches to Conservation," PLA Bulletin 28:226-31 (1973).

Dabney, Virginius. "New Ways to Permanent Files," Saturday Review, May 9, 1964, p.8788.

Darling, Pamela W. "National Planning for Preservation in the United States," Restaurator 2:205-13 (1978).

Development of Performance Standards for Binding Used in Libraries, Phase. 1I: Report on a Study Conducted by Library Technology Project. Chicago: American Library Assn., 1966.

Development of Performance Standards for Library Binding, Phase 1: Report of the Survey Team. Chicago: American Library Assn., Library Technology Project, 1961.

Duckett, Kenneth W. Modern Manuscripts: A Practical Manual for Their Management, Care, and Use. Nashville, Tenn.: American Association for State and Local History, 1975.

Dupuis, R. N.; Kusterer, J. E., Jr.; and Sproull, R. C. "Evaluation of Langwell's Vapor Phase Deacidification Process," Restaurator 1:149-64 (1970). Also in Library of Congress Information Bulletin 29:A41-43 (June 4, 1970).

"Evaluation of GBC [General Binding Corporation] Laminator," ALA Bulletin 56:56-57 (1962).

Flyate, D. M., ed. Preservation of Documents and Papers; tr. from the Russian. Published pursuant to an agreement with the U.S. Department of Commerce, the National Science Foundation, and the Council on Library Resources, Inc. Jerusalem: Israel Program for Scientific Translations, 1968.

Ford, Stephen. "The Need for New Standards for Library Binding," Library Resources \& Technical Services 5:315-21 (1961).

Foster D. Snell, Inc. "Microfilm Rejuvenation: An Evaluation of Three Treatment Services," Library Technology Reports, Sept. 1973.

[Francis, William.] "Rags to Riches: The Story of Virginia Papermaking," Arts in Virginia 4:3-26 (Spring 1964).

Grove, Lee E. "Adhesive Bookbinding: A Practice Reviewed," Library Resources \& Technical Services 6:143-60 (1962).

. "The Conservation of Paper," Museum News 42:15-20 (Oct. 1963).

. "Paper Deterioration-An Old Story," College \& Research Libraries 25:365-74 (1964). 
"Predictability of Performance in 'Perfect Library Bindings," College \& Research Libraries 22:341-44 (1961).

Haas, Warren J. "New York Conference on Book Paper and Book Preservation," Library of Congress Information Bulletin 38:298-300 (Aug. 3, 1979). Accounts also appear in National Preservation Report 1:31-35 (Aug. 1979), and CLR Recent Developments 7:2-3 (Aug. 1979).

Hey, Margaret. "Paper Bleaching: Its Simple Chemistry and Working Procedures," Paper Conservator 2:10-23 (1977).

- "The Use of the Scanning Electron Microscope in Document Restoration Problems," Restaurator 1:233-44 (1970).

"History of the Barrow Lab, or, The Thirty Years That Revolutionized Paper," Publishers Weekly 189:72-80 (April 4, 1966).

Horton, Carolyn. Cleaning and Preserving Bindings and Related Materials. $2 \mathrm{~d}$ ed., rev. (LTP Publication no.16) Chicago: American Library Assn., Library Technology Program, 1969.

Kelly, George B., Jr. "Practical Aspects of Deacidification," Bulletin of the American Group, International Institute for Conservators 13:1628 (1972). Also in Archives et Bibliotheques de Belgique, Numero Special 12:91-105 (1974).

Kusterer, James E., Jr. "Surface pH Determinations of Paper," Industrial Applications Research Data Sheet, pH-7622. Fullerton, Calif.: Beckman Scientific Instruments Division, n.d.

"Manuscript-Marking Ink," ALA Bulletin 56:361 (1962).

"Maximum Safe pH," in Clark W. Nelson, ed., "Technical Notes," American Archivist 38:6566 (1975).

Middleton, Bernard C. The Restoration of Leather Bindings. (LTP Publication no.18) Chicago: American Library Assn., Library Technology Program, 1972.

New Methods for the Restoration and Preservation of Documents and Books; ed. N. Ya. Solechnik; tr. from the Russian. Published pursuant to an agreement with the National Science Foundation and the Council on Library Resources. Jerusalem: Israel Program for Scientific Translations, 1964.

"The Paper Man," Richmond News Leader, June 8, 1963, p.3.

Permanent/Durable Book Paper. Summary of a conference held in Washington, D.C., Sept. 16, 1960. Sponsored by the American Library Association and the Virginia State Library. Richmond, Va.: Virginia State Library, 1960.

Piez, Gladys T. "Archival Containers-A Search for Safer Materials," American Archivist 27:433-38 (1964).

(1964).

"Film Coatings-Do They Really Protect
Microfilm?" National Micro-News, no.67:12539 (Dec. 1963).

- "Laminator for Libraries," ALA Bulletin 55:269-75 (1961).

- "Some Library Adhesives-A Laboratory Evaluation of P.V.A.'s [polyvinyl acetates]," ALA Bulletin 56:838-43 (1962).

Poole, Frazer G. "Performance Standards in Library Binding," Book Production 75:67-68 (June 1962).

"The Preservation Research Program of the Library of Congress," Preservation Supplement 72-73, Library of Congress Information Bulletin 31: Appendix 165-68 (Sept. 15, 1972).

"A Report on a Planning Conference for a National Preservation Program, Washington, D.C., December 16-17, 1976," Library of Congress Information Bulletin 36:129-31 (Feb. 18, 1977).

"Research Is Arresting the Rapid Deterioration of Books," New Scientist 19:138 (July 18, 1963). London.

Roberson, David D. "The Evaluation of Paper Permanence and Durability," TAPPI 59:63-69 (1976).

Shaffer, Norman J. "Library of Congress Pilot Preservation Project," College \& Research Libraries 30:5-11 (1969).

- "A Report on the Second Meeting of the Ad Hoc Advisory Committee for a National Preservation Program," Library of Congress Information Bulletin 36:841-42 (Dec. 23, 1977).

Simonton, Wesley. "The Bibliographical Control of Microforms," Library Resources \& Technical Services 6:29-40 (1962).

"The Slow Fire Consuming Our Books," Hercules Chemist, no.46:19-22 (Feb. 1963).

Smith, Richard D. "A Comparison of Paper in Identical Copies of Books from the Lawrence University, the Newberry, and the New York Public Libraries," Restaurator, supp. no.2, 1972.

. "The Extension of Book Life," Library Binder 17:36-37, 39-40 (Dec. 1970).

. "Guidelines for Preservation," Special Libraries 59:346-52 (1968).

- "New Approaches to Preservation," Library Quarterly 40:139-71 (1970).

"The Nonaqueous Deacidification of $\mathrm{Pa}$ per and Books." Ph.D. dissertation, Univ. of Chicago, 1970.

- "Paper Impermanence as a Consequence of $\mathrm{pH}$ and Storage Conditions," Library Quarterly 39:153-95 (1969).

"Test Devices Used in Binding Standards," $\mathrm{Li}$ brary Technology Reports, July 1967.

Walker, Bernard F. "Morpholine Deacidification of Whole Books," in John C. Williams, ed., Preservation of Paper and Textiles of Historic and Artistic Value, p.72-87. (Advances in 
Chemistry Series, no.164) Washington, D.C.: American Chemical Society, 1977.

Weinstein, Robert A., and Booth, Larry. Collection, Use, and Care of Historical Photographs. Nashville, Tenn.: American Association for State and Local History, 1977.

Williams, Edwin E. "Magnitude of the Paper-

Deterioration Problem as Measured by a National Union Catalog Sample," College d Research Libraries 23:499, 543 (1962).

Williams, Gordon R. "The Preservation of De- teriorating Books," Library Journal 91:51-56, 189-94 (1966).

Williams, John C., and Kelly, George B., Jr. "Research on Mass Treatments in Conservation," Bulletin of the American Institute for Conservation 14:69-77 (1974).

, and Krasnow, Marta R. "Folding Endurance and Tensile Strength of Paper," Bulletin of the American Group, International Institute for Conservators 14:25-41 (1973). 